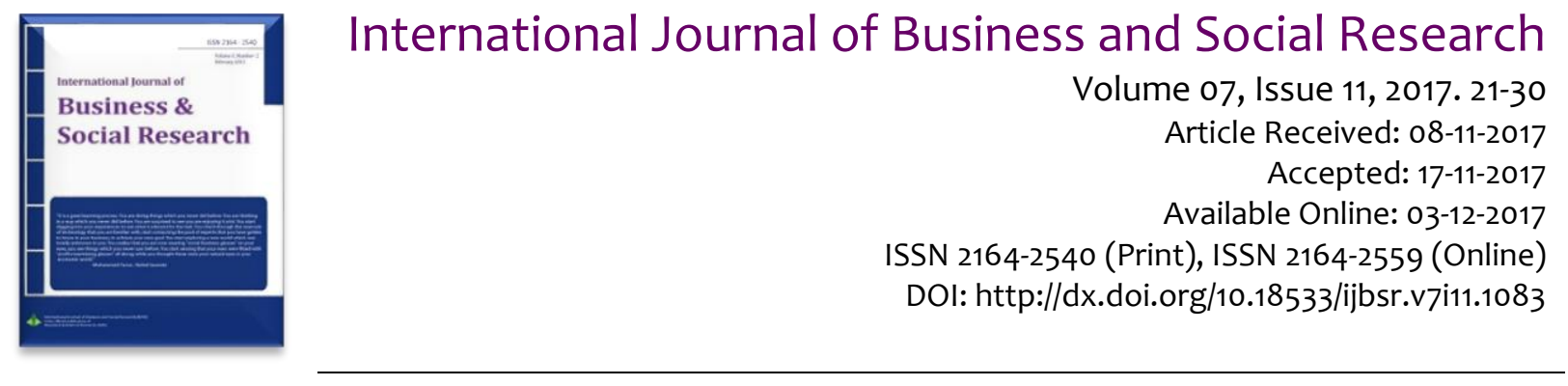

\title{
Perceived Vulnerability in Consumer Ethnocentrism
}

\author{
Jorge A Wise'
}

\begin{abstract}
This research establishes that the consumer's perceived vulnerability to a threat is a relevant variable that modifies the preference for domestic origin products. Many times, consumers balance their personal well-being with their sense of in-group identity, particularly when their preference for domestic products above foreign ones is expected. This study demonstrates that perceived vulnerability to a threat such as damaging one's personal well-being is a relevant factor when consumers express their preference for domestic products.
\end{abstract}

Keywords: Consumer Ethnocentrism, Consumer Preference, Domestic Products, Mexico, Perceived Vulnerability. JEL Codes: M13.

This is an open access article under Creative Commons Attribution 4.0 License, 2017.

\section{Introduction}

The consumer's preference for domestic products while avoiding foreign is called "consumer ethnocentrism" (Shimp, 1984). Shimp and Sharma's (1987) findings support the ethnocentric conceptualization, in which the consumer prefers the in-group products that he/she identifies with the most, and avoids the out-group products. Out-group products are perceived as not being part of the ingroup, and there is a sense of doing something inappropriate when out-group products are purchased. Ethnocentric consumers exhibit a tendency, a bias, favouring the in-group above the out-group.

An ethnocentric consumer has a negative opinion regarding the out-group products with which he/she fails to identify. In a similar manner, the ethnocentric consumer exhibits an unreasonable determination to avoid out-group products and considers it incorrect to buy them. The above assertions call for deeper analysis into the dynamics of consumer's preferences for products. Of special interest, the present research aims at understanding and modelling the analysis of perceived vulnerability as a threat to the consumer's preference for domestic products above imports.

Patriotic sentiments have been found to affect consumers' preferences for ethnocentric products among people of different countries. However, the ethnocentrism literature has failed to recognize relevant factors other than patriotism that influence the level of consumer ethnocentrism. One such relevant factor might be the individual's perceived vulnerability to a threat. The perception of a threat is assumed to inhibit risky behaviour. The perceived vulnerability to a threat refers to one's belief

\footnotetext{
${ }^{1}$ Professor of Marketing and International Business, CETYS Universidad, Mexico. Email: jorge.wise@cetys.mx
} 
about the likelihood of being affected by an event (Rosenstock, 1974), and this belief is expected to negatively influence the total effect of patriotism on the consumer ethnocentric tendencies.

The present study fills the gap found in the literature by showing that consumers modify their ethnocentric levels when preferring foreign or domestic products because they consider aspects other than patriotism, such as perceived vulnerability to a threat. This study is performed using a Mexican sample extending the actual research found in the patriotism and consumer ethnocentrism relationship. The present research examines a moderator process underlying consumers' attitudes toward imported products in their markets. First a definition of perceived vulnerability is introduced with two distinct dimensions: absolute (or individual) and comparative. Then, a discussion of the consumer ethnocentric literature is offered. Next, a series of arguments are asserted which lead to the proposed hypotheses. Finally, there is a description of the study methods and measures used to test the hypotheses that follow.

\section{Literature review}

This section deals with two different themes: first, it introduces the concept of perceived vulnerability to a threat for the first time in the marketing field; and second, a review of the literature regarding consumer ethnocentrism which is a more known construct in international marketing.

\subsection{Perceived vulnerability}

Studies of preference and choice examine the issue of how product attributes lead to consumer choice. In using a typical model (e.g. Fiske \& Taylor, 1991), scholars assume that the consumer evaluates a product in terms of its visible (accessible) attributes or cues, then processes the information via one or more beliefs, and finally forms a preference (Huber \& McCann, 1982). The visible cues refer to extrinsic product cues such as country-of-origin ( $\mathrm{COO}$ ) labels of products. The beliefs are opinions regarding what is wanted and recognized. For instance, ethnocentric consumers consider it appropriate, desirable, responsible, and moral to prefer domestic products above imports. Preference formation is the consequence of being ethnocentric; that is, accepting the in-group and rejecting the out-group at the same time. Under the previous assumptions, consumers will have a normative preference for domestic products which refers to consumer ethnocentric tendencies.

However, the research on product preference has failed to consider perceived factors related to the vulnerability to a threat. The threat is found when the consumer feels that the ethnocentric tendencies are an attack upon the consumer's well-being. Related research recognizes that such perceived vulnerability has two dimensions, one in relation to oneself (absolute) and the other in relation to others (comparative). Comparative perceived vulnerability refers to one's perception of being vulnerable in comparison to others. On the other hand, absolute perceived vulnerability indicates one's perception of being vulnerable oneself. Both approaches are relevant to consumer ethnocentric tendencies.

Comparative Perceived Vulnerability. The literature that examines vulnerability indicates that individuals tend to see themselves as less vulnerable than others. That phenomenon has been reported in health (Smith, Gerrard, \& Gibbons, 1997), risk (Taylor \& Brown, 1988), and marketing studies (Svensson, 2002). The evidence indicates that individuals' inability to make accurate estimates tends to maintain an illusion of themselves as invulnerable, or they show an optimistic bias (McKenna, 1993; Weinstein, 1980). Studies of perceived vulnerability have demonstrated that people tend to think that they are less vulnerable than others to negative events (Weinstein, 1987; Gerrard, 1991).

Absolute Perceived Vulnerability. People tend to underestimate their vulnerability in comparison to others, without denying their own vulnerability to adversity (Gerrard, Gibbons, \& Bushman, 1996). Risk literature considers that one's perception of a threat makes one feel vulnerable to unpleasant events (Slovic, Fischhoff, \& Linchenstein, 1981). An ethnocentric consumer might perceive that he/she is less vulnerable to a threat when the in-group is kept safe.

Previous research and theory suggests that absolute perceived vulnerability is related to selfesteem. Individuals with high self-esteem like to enhance their attributes and abilities, and are less likely to accept their own poor performance or carelessness (Smith, et al. 1997). Similar findings were made by Boney-McCoy, Gibbons, and Gerrard (1999) where women with high self-esteem reported lower perceived vulnerability to a threat than did women with low self-esteem. That research suggests that 
when people perceive vulnerability to a threat, they respond by focusing on positive personal qualities that reduce unwanted conditions (Abel, 1997). Bias that enhances the self helps individuals with high selfesteem to validate and maintain their positive self-perceptions and expectations.

The aim of the present study is to analyse the consumer's perception of vulnerability as a cognitive factor which will be related to consumer ethnocentrism scores. On the assumption that consumer behaviour is not random but rather a collection of organized and meaningful responses to the world as seen by the consumer (Hansen, 1972), the individual's perceived vulnerability will depend mainly on cognitive factors such as personality and attitude (Boney-McCoy, et al. 1999). When ethnocentric consumers perceive themselves to be vulnerable to a threat, their consumer ethnocentrism scores will be modified. Ethnocentric consumers will modify their preference for domestic products in order to manage vulnerability. Being ethnocentric implies a normative tendency which fails to reflect an unpredicted behaviour under the perception of vulnerability to a threat.

\subsection{The ethnocentric concept}

Ethnocentrism is a term often applied to the home country bias of the COO effect, but it is independent of the concept of origin bias (Herche, 1992). Ethnocentrism is a factor in making distinctions between in-groups (with which one identifies) and other groups. Ethnocentrism is considered a universal phenomenon, and is rooted in most areas of inter-group relations (Lewis, 1985).

The ethnocentrism concept "represents the universal proclivity for people to view their own group as the centre of the universe, to interpret social units from the perspective of their own group, and to reject persons who are culturally dissimilar while blindly accepting those who are culturally like themselves" (Shimp \& Sharma, 1987, p. 280). This definition offers an initial point for understanding the psychological aspect of group relations.

Although ethnocentrism was initially seen purely as sociological, it is studied in other fields such as social psychology, anthropology, and marketing. Ethnocentrism relates to social identity theory ("the social-identity group is the nation": Lantz \& Loeb, 1996, p. 375) which means it can be used to analyse different countries, individual personalities, and the interaction of social forms. The division of the world into countries and nationalities implies a classification of people into in-groups (their own country) and out-groups (foreign countries) (Verlegh, 1999). Out-groups are the objects of negative opinions and hostile attitudes; those groups are considered as antithetical to the in-groups (Balabanis, Diamantopoulos, Mueller, \& Melewar, 2001). In-groups are the objects of positive opinions and uncritically supportive attitudes; and comprise those groups with which one identifies oneself -and one's country. Ethnocentric persons will value their in-group as salient with cognitive consequences. Ethnocentrism can be understood as an unfavourable (negative) attitude toward out-groups accompanied by a favourable (positive) attitude toward the in-group (Sumner, 1906).

Based on the above, the concept of consumer ethnocentrism was proposed as an economic form of capturing the individual consumer's cognitions and emotions as they relate to product offerings from other countries (the out-groups). Consumer ethnocentrism was born independently of the conception of origin bias despite the fact that proponents of the consumer ethnocentrism stream consider it to be part of its domain (Shimp, \& Sharma 1987; Balabanis, et al. 2001).

The Role of Consumer Ethnocentrism Tendencies. Consumer ethnocentrism represents the tendency for individuals to view their own group (the in-group) as superior to other groups (the outgroups), to view the out-groups from their own perspective, and to reject culturally dissimilar ideas while blindly accepting culturally similar ideas and people (Netemeyer, Durvasula \& Lichtenstein, 1991; Sharma, Shimp, \& Shin 1995). It reflects a normative sense of group identity that can motivate consumers to buy their own in-group's products (Olsen, Granzin, \& Biswas 1993). Highly ethnocentric people take pride in their own values, symbols, and people, and dislike objects and values of the out-group. For them, purchasing foreign products is wrong because it hurts their domestic economy, jobs are lost, and it is unpatriotic.

Consumer ethnocentrism incorporates a feeling of doing something wrong when foreign made products are acquired (Shimp, 1984). The attitude toward imported products implies a prejudice and imports are seen by ethnocentric consumers as bad and unwanted. Consumers exhibiting the ethnocentric characteristic of unfavourable bias toward imports have the tendency to negatively 
evaluate the out-group. Preferring products with domestic origin reflects a positive and supportive perception of those products.

\section{Hypotheses}

The overall aim of the proposed empirical research is twofold. First, investigate the effect of the newly introduced concept of perceived vulnerability to a threat under the consumer ethnocentric approach; second, test whether perceived vulnerability serves as a mediator in the relationship between patriotism and consumer ethnocentric tendencies. Under the previous aim, other analyses are expected such as the joint effect and individual influence of the two dimensions of perceived vulnerability in the patriotism-consumer ethnocentric tendencies relationship.

\subsection{Perceived vulnerability as a moderator}

The positive relationship between patriotism and consumer ethnocentrism, evidenced by researchers, is likely to be moderated by the perception of vulnerability to a threat. A moderator variable is a quantitative, or qualitative, variable that affects the direction and/or strength of the relation between a predictor variable -i.e. patriotism- and a criterion variable -i.e. consumer ethnocentrism (Baron \& Kenny, 1986; Cohen \& Cohen, 1983; Erickson \& Nosanchuk, 1992; Sproull, 1988; Zadeck, 1971).

Consumers perceive products differently in terms of whether those products are relevant to them personally or to the domestic economy in general. When the preference for domestic products is seen as a threat to one's well-being, the influence of patriotism should vary depending on the direction and/or strength of the moderated effect. Therefore, there are several options to consider. On one hand, when the perceived vulnerability to a threat is small or negligible, the influence of patriotism on consumer ethnocentric tendencies will maintain or reduce the actual relationship. Thus,

$\mathbf{H}_{\mathbf{1}}$ : The lower the level of perceived vulnerability to a threat, the similar or smaller the positive impact of patriotism on consumer ethnocentric tendencies.

Translating the previous hypothesis to mathematical terms, being positive the slope between the predictor variable (patriotism) and the criterion variable (consumer ethnocentric tendencies), the influence of the moderator variable (perceived vulnerability to a threat) will maintain or increase the slope of the relationship. The previous means that when a consumer feels almost no vulnerability to a threat to one's well-being, then the consumer will maintain or diminish the preference for domestic products.

On the other hand, when the perceived vulnerability to a threat is large, the influence of patriotism on consumer ethnocentric tendencies will increase its impact in the relationship. Thus,

$\mathbf{H}_{\mathbf{1}}$ : The higher the level of perceived vulnerability to a threat, the greater the positive impact of patriotism on consumer ethnocentric tendencies.

In this case, the slope of the patriotism-consumer ethnocentrism relationship is increased; the preference for domestic products increases.

\subsection{Comparative and absolute perceived vulnerability}

The two dimensions of perceived vulnerability are considered to be independent (Weinstein, Lyon, Rothman, \& Cuite, 2000). Logical grounds indicate that both dimensions, comparative and absolute perceived vulnerability, are part of the total perceived vulnerability. Absolute and comparative perceived vulnerability are expected to moderate the effect of patriotism on consumer ethnocentric tendencies. Therefore, following the same logic previously undertaken, when the comparative perceived vulnerability to a threat is small or negligible, the influence of patriotism on consumer ethnocentric tendencies will maintain or reduce the actual relationship. Thus the following hypotheses are examined:

$\mathbf{H}_{2 \mathrm{a}}$ : The lower the level of comparative perceived vulnerability to a threat, the similar or smaller the positive impact of patriotism on consumer ethnocentric tendencies.

$\mathbf{H}_{2 \mathrm{~b}}$ : The higher the level of comparative perceived vulnerability to a threat, the greater the positive impact of patriotism on consumer ethnocentric tendencies.

$\mathbf{H}_{3 \mathbf{a}}$ : The lower the level of absolute perceived vulnerability to a threat, the similar or smaller the positive impact of patriotism on consumer ethnocentric tendencies. 
$\mathbf{H}_{3 \mathbf{b}}$ : The higher the level of absolute perceived vulnerability to a threat, the greater the positive impact of patriotism on consumer ethnocentric tendencies.

\subsection{Patriotism as predictor of consumer ethnocentrism}

The influence of patriotism (Jordan, 1904) on consumer ethnocentrism has been suggested since Adorno, et al. (1969) due to it's closely linkage with the more general construct of ethnocentrism. Based on the works by Han (1988), Shimp and Sharma (1987), Klein and Ettenson (1999) among others who found a positive relationship, thus:

$\mathrm{H}_{4}$ : Patriotism will be positively related to consumer ethnocentrism.

The above hypotheses and the control variables with the postulated relationships are summarized in Figure 1.

Figure 1: Expected links of patriotism and perceived vulnerability with consumer ethnocentric tendencies

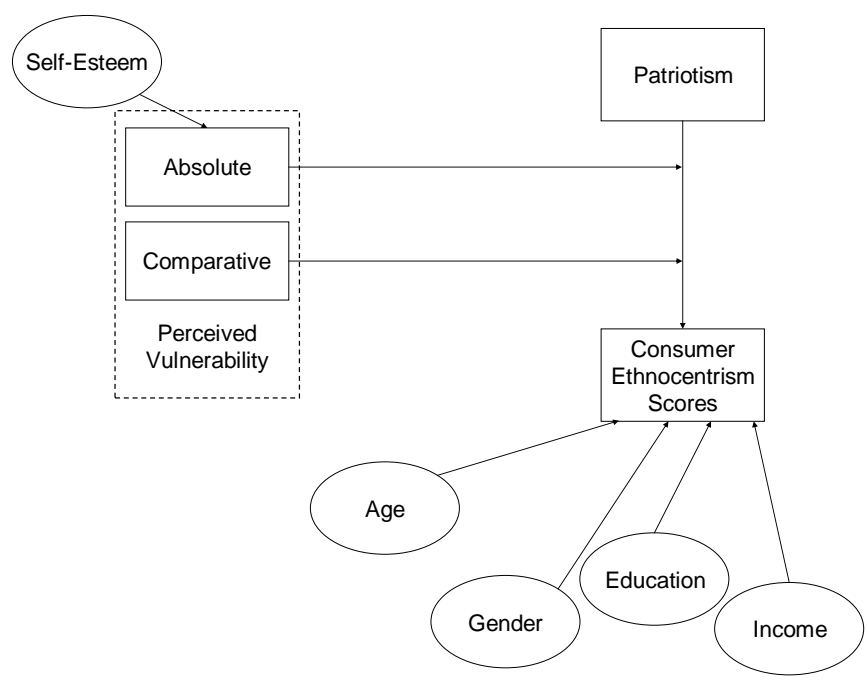

\section{Research methodology}

The model in Figure 1 is tested empirically using moderated regression analysis (MRA). The theory here considered leads us to be interested in how the variables are interrelated and to develop a system of equations which specifies all the causal linkages among the variables. In this case, the proposed research asks how patriotism and perceived vulnerability (with its two dimensions) are related to consumer ethnocentrism.

The regression equation for the path model is:

$C E T=a+b_{1}$ PAT $+b_{2}$ TPV $+b_{3}$ PATXTPV

Where:

$$
\begin{aligned}
& \text { CET }=\text { Consumer Ethnocentrism Tendencies } \\
& \text { PAT }=\text { Patriotism } \\
& \text { TPV }=\text { Total Perceived Vulnerability }
\end{aligned}
$$

\subsection{Operationalization of the variables}

Perceived vulnerability. Perceived vulnerability has been operationalized in various ways for the health belief model and in the health literature. Researchers have generated specific questions to measure personal vulnerability in every case. Although there have been some efforts to measure perceived vulnerability, until now, the literature has failed to include a full scale to measure this, because the concept of perceived vulnerability represents a subjective perceived risk with different cognitive understandings for everyone (Durvasula, Andrews \& Netemeyer, 1997). The scales include concepts related to unpleasant events that might happen in the future. The lower scores on the scales represent smaller levels of perceived vulnerability. For the present study, the future unpleasant event is the reduction of well-being resulting from following the normative consumer ethnocentric tendencies. Thus, 
to measure absolute and comparative perceived vulnerability specific questions are introduced in order to consider any damage to one's well-being. In this case, well-being refers to one's own interpretation of standard of living and quality of life.

Patriotism. The measure used to operationalize the construct of patriotism is drawn from the literature and had been previously shown to be psychometrically sound. Patriotism is measured on the scale developed by Kosterman and Feschbach (1989).

Consumer Ethnocentric Tendencies. For the measurement of consumer ethnocentric tendencies, the Consumer Ethnocentrism Tendency Scale, or CETSCALE, developed by Shimp and Sharma (1987) is used. The 17-items scale has been extensively used and validated (Netemeyer, et al. 1991; Durvasula, et al. 1997; Steenkamp \& Baumgartner 1998) in Mexico and many other countries.

Self-esteem. The Rosenberg Self-Esteem Scale, or RSES (Rosenberg, 1965), is considered in order to measure both trait self-esteem and state self-esteem. The RSES has been employed to analyse perceived vulnerability under the health approach, and it is considered appropriate in consumer ethnocentrism research.

\subsection{Methodological considerations}

Translation of the Instruments. All the scales used were originally developed in English, their translation into the sample's language was necessary. As the study is done in Mexico, the instruments should have equivalent meaning in the research context to be studied (Green \& White, 1976). All the instruments were translated into the Spanish spoken in Mexico using the back-translation technique (Parameswaran \& Yaprak, 1987).

Data Collection. The present study is done using Mexican consumers by personal interviewing. Personal interviewing is recognized as the most flexible method of obtaining research data (Craig \& Douglas, 2000). The respondent is clearly identified and the sample distribution can be controlled. Personal interviews allow the interviewer to clarify and explain questions if needed.

The sample is drawn from consumers waking in a business district area in a large state capital city in northeast Mexico. Data is collected by the researcher and local collaborators on the main streets and/or in the squares of the main shopping district in town (Bush \& Hair, 1985) similarly to what others have done earlier researching consumer ethnocentrism (Balabanis, et al. 2001). The sample size is 313 similar to the sample size used in Turkey by Sharma, et al. (1995) which is psychological comforting (Churchill \& lacobucci, 2002).

Determination of the Moderator Effect. The MRA (Sharma, Durand, \& Gur-Arie, 1981) is used to identify moderator variables. The MRA is an analytical approach which maintains the integrity of the sample while provides a basis for controlling the effects of a moderator variable. This analysis involves prediction equations for the total sample and do not require explicit subgrouping or differentiating of individuals.

\section{Results and discussion}

\subsection{Characteristics of the sample}

The average income represents Mexico's Socio-Economic Level D+ where most of the population concentration (30.4\%) was expected (AMAI, 2004). Despite that fact, the sample income distribution is comparable to the general population. The respondents' average level of education represents a level bit higher that high-school (12 years). Subjects in the sample seem to be more educated than the average population. The sample female/male ration is very similar to the same ration in the general population. Similarly, the age distribution of the sample follows a comparable distribution as the general population (INEGI, 2003).

In all the cases the variables Cronbah's alpha are higher than the commonly accepted value of .70 (Nunnally \& Bernstein, 1994). The only exception is the 12-Item Patriotism scale which in the pilot test showed similar problems.

Rather, the five items with alpha large enough to be considered in the study obtained by factor analysis in the pilot test correspond to the patriotism reduced scale which also accounted for a high alpha 
with the sample employed. In general, the sample Cronbah's alphas show higher values than the ones obtained in the pilot test for most of the variables.

\subsection{Test of moderator effect}

MRA was used to test $\mathrm{H}_{1 a}$ to $\mathrm{H}_{3 \mathrm{~b}}$. These hypotheses posited that the impact of patriotism (PAT) on consumer ethnocentric tendencies (CET) would have an effect moderated by the intensity of perceived vulnerability (PV) to a threat. The models for each of the three factors analysed are found in Table 1.

Coefficients $b_{1}$ and $b_{2}$ in equations 3 and 4 are significant $(p=.000)$ implying that both independent variables have an effect on the dependent one. However, when the interaction of the independent variables is added (equations 5), the effect of perceived vulnerability is not significant for CET values.

The effect of the patriotism and perceived vulnerability interaction is analysed in equations 5 . The results in the three models are similar. Perceived vulnerability is not significant $(p>.050)$ while the interaction has become significant. Moreover, the significant level of patriotism diminishes as the $p$ levels increase. However, the interaction significant level $(p=.000)$ indicates a moderator effect. Moderation is indicated when the interaction between perceived vulnerability and patriotism is statistically significant. In this case, perceived vulnerability, total and its two dimensions, is found to be a pure moderator variable. The interaction of both patriotism and perceived vulnerability factors has a positive effect on the influence of patriotism on consumer ethnocentric tendencies due to the positive value of the interaction coefficients, i.e. $b_{3}$ in equations 5 .

Table 1: Moderator regression analysis results

\begin{tabular}{|c|c|c|c|c|c|c|}
\hline & & a & $b_{1}$ & $b_{2}$ & $b_{3}$ & $\mathrm{R}^{2}$ \\
\hline \multirow[t]{2}{*}{$(E q 3)$} & $\mathrm{CET}=\mathrm{a}+\mathrm{b}_{1} \mathrm{PAT}$ & 22.599 & 1.412 & & & 0.089 \\
\hline & plevel & 0.029 & 0.000 & & & \\
\hline \multirow[t]{2}{*}{$(\mathrm{Eq} 4 a)$} & $\mathrm{CET}=\mathrm{a}+\mathrm{b}_{1} \mathrm{PAT}+\mathrm{b}_{2} \mathrm{TPV}$ & 5.217 & 1.330 & 0.837 & & 0.191 \\
\hline & p level & 0.606 & 0.000 & 0.000 & & \\
\hline \multirow[t]{2}{*}{$($ Eq $5 a)$} & $C E T=a+b_{1} P A T+b_{2} T P V+b_{3}$ PATxTPV & 36.067 & 0.564 & -0.408 & 0.006 & 0.230 \\
\hline & plevel & 0.003 & 0.056 & 0.195 & 0.000 & \\
\hline \multirow[t]{2}{*}{$(E q 4 b)$} & $\mathrm{CET}=\mathrm{a}+\mathrm{b}_{1} \mathrm{PAT}+\mathrm{b}_{2} \mathrm{APV}$ & 12.131 & 1.290 & 1.323 & & 0.174 \\
\hline & p level & 0.225 & 0.000 & 0.000 & & \\
\hline \multirow[t]{2}{*}{$(E q 5 b)$} & $C E T=a+b_{1} P A T+b_{2} A P V+b_{3}$ PATXAPV & 39.594 & 0.614 & -1.068 & 0.112 & 0.214 \\
\hline & p level & 0.001 & 0.035 & 0.090 & 0.000 & \\
\hline \multirow[t]{2}{*}{$(\mathrm{Eq} 4 \mathrm{C})$} & $\mathrm{CET}=\mathrm{a}+\mathrm{b}_{1} \mathrm{PAT}+\mathrm{b}_{2} \mathrm{CPV}$ & 3.634 & 1.403 & 1.476 & & 0.174 \\
\hline & plevel & 0.726 & 0.000 & 0.000 & & \\
\hline \multirow[t]{2}{*}{$(E q 5 C)$} & $\mathrm{CET}=\mathrm{a}+\mathrm{b}_{1} \mathrm{PAT}+\mathrm{b}_{2} \mathrm{CPV}+\mathrm{b}_{3} \mathrm{PAT} x \mathrm{CPV}$ & 35.924 & 0.603 & -0.931 & 0.114 & 0.221 \\
\hline & $p$ level & 0.004 & 0.045 & 0.126 & 0.000 & \\
\hline
\end{tabular}

Once the interaction effect is found and the moderator effect has been established, the type of moderator variable is ascertained. The relationship is established analysing the correlations of the dependent variable (CET) and the purposed moderated factors. Perceived vulnerability, total and its two dimensions, is significantly related $(p=.000)$ to the CET scores. Hence, perceived vulnerability is considered a pure moderator variable and influences the relationship included in equations 5 . Following MRA, as perceived vulnerability is not statistically related to CET no other analysis is necessary. In order to prevent the unique relation between the predictor variable and the dependent variable and to assure their quality, an additional test shows that patriotism and perceived vulnerability with its two dimensions fail to evince multicollinearity problems (VIF $=1.000)$.

By following the MRA procedure above, the evidence indicates that perceived vulnerability is a pure moderator variable that affects the impact of patriotism on consumer ethnocentric tendencies. The impact of the interaction by both perceived vulnerability and patriotism seems to be positive. As patriotism has a positive impact on consumer ethnocentrism, having a high level of patriotism will have 
a positive impact on ethnocentrism increasing its level. According to the analysis, perceived vulnerability interacts with patriotism to influence its impact on the ethnocentrism level. Thus, the interaction of the two factors impacts positively the positive impact of patriotism on consumer ethnocentrism. The aforementioned provides support for hypotheses $\mathrm{H}_{1 b}, \mathrm{H}_{2 \mathrm{~b}}$, and $\mathrm{H}_{3 \mathrm{~b}}$. As competitive hypotheses, $\mathrm{H}_{1 \mathrm{a}}, \mathrm{H}_{2 \mathrm{a}}$, and $\mathrm{H}_{3 a}$ are rejected due to the positive influence of the interaction of interest.

The findings support the conception that perceived vulnerability has an impact on the interaction between patriotism and ethnocentrism. Thus, despite the direct and positive effect of the level of patriotism on the level of consumer ethnocentrism, such impact is affected by the moderating effect of perceived vulnerability. The evidence indicates that one's beliefs about the likelihood of being affected by an event (i.e. perceived vulnerability, total and its two dimensions: absolute and comparative) is a relevant factor which affects the interaction.

\subsection{The patriotism factor}

In support of hypotheses $\mathrm{H}_{4}$, the correlation between patriotism and consumer ethnocentricity is predictably positive $(r=.304, p=.000)$, which indicates the individuals who love their country are ethnocentric. The regression analysis of the two variables (equation 3 in Table 1$)$ also supports $\mathrm{H}_{4}(b=$ $1.412, p=.000, R^{2}=.089$ ). Due to the positive correlation between the two factors, when the love for one's country increases, the preference for domestic products will also be augmented.

\section{Limitations and further research}

No study is free of different kind of limitations. A limitation of this study is its cross-sectional design. Though the inclusion of control variables will help to understand some alternative explanations for the findings, others will not be so readily noticed. An important step for further research is the collection and analysis of longitudinal data to discover other alternative explanations.

Another area that deserves further attention is the sample used which is limited to a city and will not reflect the whole country, Mexico. On the other hand, both the pilot test and actual sample originally showed a less than desired reliability of the patriotism scale. Thus, without compromising its psychometric properties, the scale was reduced (Netemeyer, Pullig, \& Bearden, 2002) obtaining appropriate levels of reliability and internal consistency. Further research of the patriotism construct with non-English speaking samples will enlighten its marketing usage.

Finally, the topic of social desirability (Crowne \& Marlowe, 1960) has almost not previously been researched on consumer ethnocentrism. Social desirability is commonly understood as the tendency to project favourable images of oneself during social interaction. Hult, Keillor, and Lafferty (1999) offer findings suggesting that the personality trait to report information that is social desirable on consumer ethnocentrism appears to be different for males and females. In general, persons scoring high on social desirability tend to over-report socially desirable and under-report socially undesirable information about themselves (Johnson, Fendrich, \& Hubbell, 2002). As most of the scales used in this study could be considered as social desirable, further research will require the inclusion of scales which account for social desirability to examine any bias.

The previous limitations can be viewed as trade-offs to the advance in the field. In marketing, despite recent efforts, as most research is done in the USA, relatively little research attempts to examine international marketing issues on the basis of data collection in other countries. This research highlights the importance of examining consumer research in other countries. The major propose of this study is not to develop or test psychometrically rigorous scales but to test the proposed hypotheses using a Mexican sample. In the final analysis, any problems with scale reliability merely render conservative the strength of the observed effects.

\section{References}

Abel, M. H., (1997). The Role of Self-Esteem in Typical and Atypical Changes in Expectations. The Journal of General Psychology, 124, 113-127.

Adorno, T. W., Frenkel-Brunswik, E., Levinson, D. J., \& Nevitt Sanford, N. (1969) The Authoritarian Personality. New York: W. W. Norton \& Company.

AMAI (2004, October 3). Niveles Socioeconómicos. Asociación Mexicana de Agencias de Investigación de Mercado y Opinión Pública, A.C. Retrieved from http://www.amai.org 
Balabanis, G., Diamantopoulos. A., Mueller, R. D., \& Melewar, T. C., (2001). The Impact of Nationalism, Patriotism and Internationalism on Consumer Ethnocentric Tendencies. Journal of International Business Studies, 32, 157-175.

Baron, R. M., \& Kenny, D., (1986). The Moderator-mediator Variable Distinction in Social Psychological Research: Conceptual, Strategic, and Statistical Considerations. Journal of Personality and Social Psychology, 51, 1173-1182.

Boney-McCoy, S., Gibbons, F. X., Gerrard, M., (1999). Self-Esteem, Compensatory Self-Enhancement, and the Consideration of Health Risk. Personality and Social Psychology Bulletin, 25, 954-965.

Bush, A. J., Hair, J. F. Jr., (1985). An assessment of the mall intercept as a data collection method. Journal of Marketing Research, 22, 158-167.

Churchill, G. A. Jr., \& lacobucci, D., (2002). Marketing Research: Methodological Foundations. Fort Worth: Harcourt College Publishers.

Cohen, J., \& Cohen, P., (1983). Applied Multiple Regression/Correlation Analysis for Behavioural Sciences. Hillsdale, NJ: Lawrence Erlbaum Associates, Publishers.

Craig, C. S., \& Douglas, S., (2000). International Marketing Research. New York: Wiley.

Crowne, D. P., \& Marlowe, D., (1960). A New Scale of Social Desirability Independent of Psychopathology. Journal of Consulting Psychology, 24, 349-354.

Durvasula, S., Andrews, J. C., \& Netemeyer, R. G., (1997). A Cross-Cultural Comparison of Consumer Ethnocentrism in the United States and Russia. Journal of International Consumer Marketing, 9, 7393.

Erickson, B. H., \& Nosanchuk, T. A., (1992). Understanding Data. Newbury Park, Ca.: Sage.

Fiske, S. T., \& Taylor, S. E., (1991). Social Cognition. New York: McGraw-Hill.

Gerrard, M., (1991). Effects of reviewing risk-relevant behaviour on perceived vulnerability among women marines. Health Psychology, 10, 173-179.

Gerrard, M., Gibbons, F. X., \& Bushman, B. J., (1996). Relation between Perceived Vulnerability to HIV and Precautionary Sexual Behaviour. Psychological Bulletin, 119, 309-409.

Green, R. T., \& White, P. D., (1976). Methodological Considerations in Cross-National Consumer Research. Journal of International Business Studies, 7, 81-88.

Han, C. M., (1988). The Role of Consumer Patriotism in the Choice Domestic versus Foreign Products. Journal of Advertising Research, 28, 25-32.

Hansen, F., (1972). Consumer Choice Behaviour: A Cognitive Theory. New York: Free Press.

Herche, J., (1992). A Note on the Predictive Validity of the CETSCALE. Journal of the Academy of Marketing Science, 20, 261-264.

Huber, J., \& McCann, J., (1982). The Impact of Inferential Beliefs on Product Evaluations. Journal of Marketing Research, 19, 342-333.

Hult, G. T. M., Keillor, B. D., \& Lafferty, B. A., (1999). A Cross-National Assessment of Social Desirability Bias and Consumer Ethnocentrism. Journal of Global Marketing, 12, 29-43.

INEGI, (2003, October 3). XII censo de población y vivienda 2000. Instituto Nacional de Estadística Geografía e Informática. Retrieved from http://inegi.org.mx.

Johnson, T. P., Fendrich, M., \& Hubbell, A., (2002). A Validation of the Crowne-Marlowe Social Reliability Scale. Proceedings of the 57th Annual Meeting of the American Association for Public Opinion Research (pp.1661-1666). St. Pete Beach, Florida.

Jordan, A., (1904). The Bias of Patriotism. International Journal of Ethics, 15, 1-27.

Klein, J. G., \& Ettenson, R., (1999). Consumer Animosity and Consumer Ethnocentrism: An Analysis of Unique Antecedents. Journal of International Consumer Marketing, 11, 5-24.

Kosterman, R., \& Feshbach, S., (1989). Toward a Measure of Patriotic and Nationalistic Attitudes. Political Psychology, 10, 257-274.

Lantz, G., \& Loeb, S., (1996). Country of Origin and Ethnocentrism: An Analysis of Canadian and American Preferences using Social Identity Theory. Advances in Consumer Research, 23, 374-378.

Lewis, I. M., (1985). Social Anthropology in Perspective: The Relevance of Social Anthropology. New York: Cambridge University Press.

McKenna, F. P., (1993). It won't Happen to Me: Unrealistic optimism or Illusion of Control. British Journal of Psychology, 84, 39-50. 
Netemeyer, R. G., Durvasula, S., \& Lichtenstein, D., (1991). A Cross National Assessment of the Reliability and Validity of the CETSCALE. Journal of Marketing Research, 28, 320-327.

Netemeyer, R. G., Pullig, C., \& Bearden W. O., (2002). Observations on Some Key Psychometric Properties of Paper-and-Pencil Measures, in: Woodside, A. G., \& Moore, E. M. (Eds.), Essays by Distinguished Marketing Scholars of the Society for Marketing Advances (pp.115-138). Boston: JAI Presston.

Nunnally, J. C., \& Bernstein, I. H., (1994). Psychometric Theory. New York: McGraw-Hill.

Olsen, J. E., Granzin, K. L., \& Biswas, A., (1993). Influencing Consumers Selection of Domestic Versus Imported Products: Implications for Marketing Based on a Model of Helping Behaviour. Journal of the Academy of Marketing Science, 21, 307-321.

Parameswaran, R., \& Yaprak, A., (1987). A Cross-National Comparison of Consumer Research Measures. Journal of International Business Studies, Spring, 35-49.

Rosenberg, M., (1965). Society and the Adolescent Self-image. Princeton: Princeton University Press.

Rosenstock, I. M., (1974). Historical Origins of the Health Belief Model. Health Education Monographs, 2, 1-8.

Sharma, S., Durand, R. M., \& Gur-Arie, O., (1981). Identification and Analysis of Moderator Variables. Journal of Marketing Research, 18, 291-300.

Sharma, S., Shimp, T. A., \& Shin, J., (1995). Consumer Ethnocentrism: A Test of Antecedents and Moderators. Journal of the Academy of Marketing Science, 23, 26-37.

Shimp, T. A., (1984), Consumer Ethnocentrism: The Concept and a Preliminary Empirical Test. Advances in Consumer Research, 11, 285-290.

Shimp, T. A., \& Subhash, S., (1987). Consumer Ethnocentrism: Construction and Validation of the CETSACALE. Journal of Marketing Research, 24, 280-289.

Slovic, P., Fischhoff, B., Linchenstein, S., (1981). Facts and Fears: Societal Perception of Risk. Advances in Consumer Research, pp. 497-502.

Smith, G. E., Gerrard, M., \& Gibbons, F. X., (1997). Self-Esteem and the Relation between Risk Behaviour and Perceptions of Vulnerability to Unplanned Pregnancy in College Women. Health Psychology, 16, 137-146.

Sproull, N. L., (1988), Handbook of Research Methods: A Guide for Practitioners and Students in the Social Sciences. Metuchen, NJ:The Scarecrow Press, Inc.

Steenkamp, J. B. E. M., \& Baumgartner, H., (1998). Assessing Measurement Invariance in Cross-National Consumer Research. Journal of Consumer Research, 25, 78-90.

Sumner, W. G., (1906). Folkways: A Study of Sociological Importance of Usages, Manners, Customs, Mores, and Morals. Boston: Ginn \& Co.

Svensson, G., (2002). Vulnerability Scenarios in Marketing Channels. Supply Chain Management: An International Journal, 7, 322-333.

Taylor, S. E., \& Brown, J. D., (1988). Illusion and Well-Being: A Social Psychological Perspective on Mental Health. Psychological Bulletin, 103, 193-210.

Verlegh, P. W. J., (1999). Ingroups, Outgroups and Stereotyping: Consumer Behaviour and Social Identity Theory. Advances in Consumer Research, pp. 162-164.

Weinstein, N. D., (1980), Unrealistic Optimism about future Life Events. Journal of Personality and Social Psychology, 39, 806-820.

Weinstein, N. D., (1987). Unrealistic Optimism about Susceptibility to Health Problems: Conclusions from a Community-Wide Sample. Journal of Behavioural Medicine, 10, 481-500.

Weinstein, N. D., Lyon, J. E., Rothman, A. J., \& Cuite, C. L., (2000). Changes in Perceived Vulnerability following Natural Disaster. Journal of Social and Clinical Psychology, 19, 372-395.

Zadeck, S., (1971). Identification of Moderator Variables by Discriminant Analysis in a Multipredictable Group Validation Model. Journal of Applied Psychology, 55, 364-371. 